IRSTI 81.93.25

UDC 338.465.4, 369.041

https://doi.org/10.46914/1562-2959-2021-1-4-54-61

\author{
B.A. ZHAKUPOVA, $* 1$ \\ c.e.s., associate professor. \\ *e-mail: bakitgul_75kz@mail.ru \\ S.I. IGILMANOVA, ${ }^{1}$ \\ senior lecturer. \\ e-mail: saule72kz@mail.ru
}

N.B. KALYUZHNAYA, ${ }^{1}$

senior lecturer.

e-mail:natk-78@mail.ru

B.S. BIMBETOVA, ${ }^{1}$

senior lecturer.

e-mail: bikon_s@mail.ru

${ }^{1}$ Aktobe regional university named

after K. Zhubanov, Kazakhstan, Aktobe

\title{
THE MAIN PRIORITIES OF USING AND MANAGING THE FUNDS OF THE UNIFIED ACCUMULATIVE PENSION FUND OF THE REPUBLIC OF KAZAKHSTAN
}

\begin{abstract}
The purpose of the article is the formation of an optimal model of pension provision of citizens in accordance with the modern market economy on the most important issues arising in the accumulative pension system of the Republic of Kazakhstan, strengthening its theoretical, methodological and legal foundations. The Republic of Kazakhstan was one of the first CIS countries to start pension reform 24 years ago. The main goal is to establish the personal responsibility of each citizen of Kazakhstan for his financial situation when reaching retirement age. In this regard, when implementing the reform, the state policy envisaged a gradual transition from the application of the principle of cooperation between generations to independent savings in pension funds. The pension reform in Kazakhstan was carried out optimally and the World Bank recognized it as one of the most successful reforms. The accumulative pension system plays a significant role in the life of the country, the development of the stock market and the improvement of the national economy, the distribution of long-term investments at the expense of domestic savings to increase the competitiveness of the country. In order to become one of the 30 effectively developed countries of the world, the state has created high standards of living for the citizens of Kazakhstan by improving the level and quality of pension provision. For this, one of the most important components of the economic and social conditions of the population is that accumulative pension funds in Kazakhstan should develop further, and the pension system should be competitive. The main pillar of the accumulative pension system in the country is the improvement of the accumulative pension fund and effective pension provision, which forms the basis of the future population. In the conditions of modern globalization and rapid development of financial markets, the financial position of the accumulative pension fund, a participant in the financial market, and its effective functioning are in the first place.
\end{abstract}

Key words: pension, pension fund, pension system, savings, deposits, funds, capital.

\section{Introduction}

In understanding with the Structure of the Republic of Kazakhstan, the creation of a social state is the main objective of Social Development. Therefore, the issue of pension provision undoubtedly occupies an important place in the economic policy of any country in the world. During the period of the beginning of the pension reform in Kazakhstan from 1998 to 2013, more than 10 funds operated as a joint stock company of individual pension funds. The successful functioning of such funds directly depends on the position of the founders and the number of depositors.

\section{Literature review}

The issues of the pension system were summarized as a special scientific work on the basis of scientific research of scientists, topical articles were published at international practical conferences, 
priority was given to the President's messages, several laws and strategic programs were developed, and regulatory legal acts were issued. Scientific research on the implementation of the accumulative pension system of near and far abroad countries was conducted, which considered foreign specialists and their reforms. Kazakhstan's activities in this direction were highly appreciated by Western experts in their research, which summed up the world's achievements in implementing pension reform based on the accumulative pension system. As an experiment, the state of Kazakhstan came to the conclusion that the pension system should be implemented on the model of the state of Chile, and in this regard, based on the experience of this state, a pension center was opened in Kazakhstan in 1997 and began to work on this reform.

\section{Basic Rules}

In 1998, Kazakhstan was the first country in the CIS region to begin a planned transition to the accumulative pension system. Currently, Kazakhstan has pension systems "solidarity" (for current pensioners and persons who have worked for at least 6 months on January 1, 1998) and "accumulative" (for people who have started transferring $10 \%$ of their salary to accumulative pension funds since January 1, 1998). The activities of the pension system of the population are related to the activities of state and non-state funds. It is carried out according to the scheme shown in Figure 1.

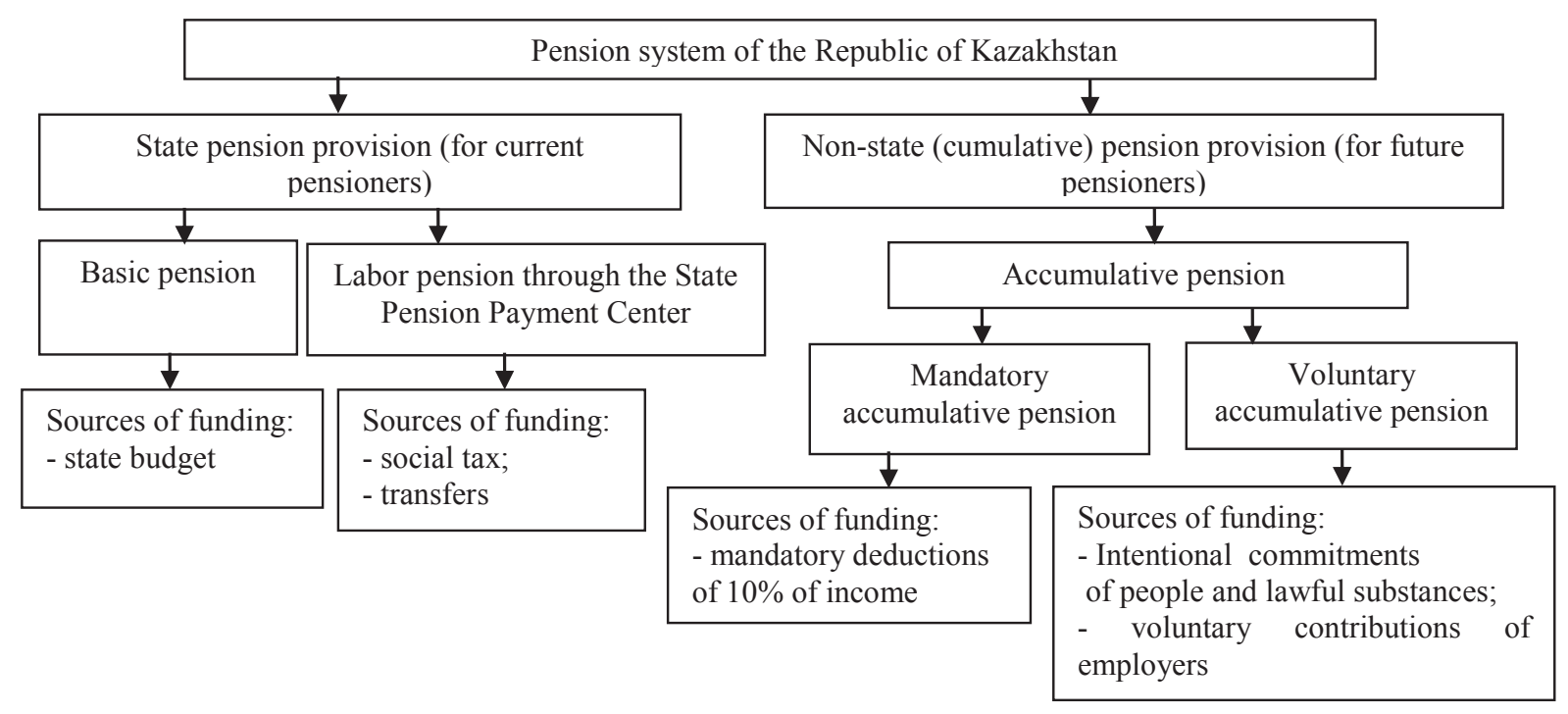

Figure 1 - Pension system of the Republic of Kazakhstan

"One of the priorities of the address of the president of the Republic of Kazakhstan to the people of Kazakhstan dated December 14, 2012 "Strategy «Kazakhstan-2050" "new political course of the established state" "is to improve the material and social standard of living of the population, strengthen social stability and protection, which, in turn, will lead to the development of pension provision" [1-3].

\section{Materials and methods}

Systematic and logical approaches to solving the tasks set in the study, methods of analysis, deduction, induction were used to form a general understanding of the pension system of Kazakhstan. In addition, for analytical review, methods of comparative analysis of economic phenomena were used to determine the positive and negative dynamics of the UAPF. The data of the UAPF as an information source for the study were taken as a basis during the analysis.

\section{Results}

Agreeing to the comes about of the investigation, the main problems in the advancement of the aggregate annuity framework are: insufficient amount of pension savings necessary to ensure a sufficient level of pension payments in old age; insufficient coverage of the population with UAPF 
services; moo level of money related education and speculation culture of the populace; need of successful venture of benefits reserve funds in conditions of a deficiency of dependable and fluid securities.

In this regard, on the basis of improving the activities of the UAPF, the following measures should be implemented today: improving the quality of UAPF services and improving the risk management structure; creating a reliable institutional infrastructure of the pension system; improving regulatory legal acts of the UAPF; improving remote supervision of the UAPF's activities and increasing its transparency; increasing the domestic investment market and the range of financial instruments provided, developing the market of industrial financial instruments; ensuring the most effective and fair system of pension provision of citizens after reaching retirement age; increasing citizens ' confidence in the accumulative pension system; improving financial literacy and investment culture of citizens.

Accumulative pension funds, established in Kazakhstan in 1998, have served the population for 15 years. However, today Kazakhstanis have forgotten that the pension system was different before the reform. The former system, which was used in Soviet times and did not respond to the principles of General justice, immediately after the collapse of the USSR showed that the future of its activities was blurred. For 15 years, the new reform has not only been effective and effective, but also the cause of the global financial crisis, which has taken place in the current conditions, has not affected pension savings [4-6]. In accordance with the law on the Republican budget for 2021, the monthly calculation index and the subsistence minimum have changed, and other financial indicators are shown in Table 1.

Table 1 - Financial indicators

\begin{tabular}{|l|c|c|}
\hline \multicolumn{1}{|c|}{ Indicators } & 2020 & 2021 \\
\hline State basic pension & 17641 & 18524 \\
\hline Minimum pension & 40441 & 43272 \\
\hline $\begin{array}{l}\text { Minimum subsistence level for calculation } \\
\text { of basic social payments }\end{array}$ & 32668 & 34302 \\
\hline $\begin{array}{l}\text { Disability payments, including: } \\
\text { - Disabled people of Group I; }\end{array}$ & 62723 & 65860 \\
- Disabled people of Group II; & 49983 & 52483 \\
- Disabled people of Group III. & 33975 & 35675 \\
\hline Poverty line in Kazakhstan & 22868 & 24011 \\
\hline Monthly calculation index (MCI) & & 2917 \\
\hline
\end{tabular}

In 2021, 721 thousand citizens were able to receive the minimum amount of funds required for early use of their funds in the UAPF. Citizens who work on a permanent basis and earn an average salary will be able to use part of the pension fund if their savings exceed the sufficient limit (the limit of the sufficient amount is a lifetime savings not less than the minimum pension in the pension account). Depositors can spend more than enough money on solving their housing problems, treatment, or transfer contributions to private pension asset management companies for investment. Data on the number of individual pension accounts of UAPF depositors and the number of opened accounts are presented in Table 2 below.

Table 2 - Pension accounts opened for UAPF depositors

\begin{tabular}{|l|c|}
\hline \multicolumn{1}{|c|}{ Indicators } & Number of accounts \\
\hline Number of individual pension accounts of depositors, total, including: & 11483507 \\
\hline Mandatory pension contributions (MPC) & 10909335 \\
\hline Mandatory professional pension contributions (MPPC) & 526682 \\
\hline Voluntary pension contributions (VPC) & 47490 \\
\hline
\end{tabular}

3 categories of citizens who receive part of the UAPF's funds:

- working citizens who have savings in the pension fund (if the savings exceed the sufficient amount). Now there are 529.7 thousand such citizens in Kazakhstan. Therefore, it is impossible to withdraw all the savings from the pension fund, some of the funds must remain in the fund; 
- people who have savings in the UAPF and have reached retirement age can use up to $50 \%$ of the fund's funds. Currently, 178.4 thousand pensioners have the opportunity to use their savings in Kazakhstan. This category also includes law enforcement pensioners. The pension of this category of citizens received from the state, including the basic pension and payments received by the UAPF, should not be less than $40 \%$ of their income at the time of retirement, in Kazakhstan this figure reached $63 \%$;

- citizens (about 13.3 thousand people) who have left savings in the UAPF after registration of a pension annuity and transfer to the insurance fund.

The threshold of sufficient size is the amount that allows a citizen to receive at least the minimum pension after retirement until the age of 82 , when contributions are regularly made before retirement age in the amount of at least the minimum wage. The main characteristic of the threshold of sufficient size: for men and women, the indicator is set equally; the threshold of sufficient size is calculated annually (depending on the amount of income, the level of inflation and the amount of the minimum payment); the threshold of sufficient size is set separately for each age (from 20 years). The amount of the threshold amount sufficient for a citizen to use part of the savings in the pension fund is calculated based on the age level of the citizen, and its amount is shown in Table 3 below.

Table 3 - Opportunities for withdrawing savings from the UAPF

\begin{tabular}{|l|c|}
\hline Age level of a citizen & Appropriate amount, in tenge \\
\hline On the point of a 30-year-old citizen & 2500000 \\
\hline On the point of a 35-year-old citizen & 2940000 \\
\hline On the point of a 40-year-old citizen & 3420000 \\
\hline On the point of a 45-year-old citizen & 3930000 \\
\hline On the point of a 50-year-old citizen & 4470000 \\
\hline On the point of a 55-year-old citizen & 5060000 \\
\hline On the point of a 59-year-old citizen & 5560000 \\
\hline
\end{tabular}

Also, these citizens can use the funds received from the savings to purchase housing for themselves, their spouse and close relatives or spend on treatment. According to the law, close relatives include grandparents, parents, children, grandchildren and siblings. It is also possible to combine the funds of family members for their intended use. If all the requirements are met, citizens have the opportunity to repeatedly withdraw funds from their pension fund savings. According to the UAPF data for the first half of 2021, to date, 1,560.7 billion tenge has been allocated from the pension fund. Tenge was used to pay for treatment. Information on the goals and directions of use of funds received from the fund's savings is contained in Table 4 (p. 58).

The authorized operator that oversees the process of spending funds from the pension fund to solve housing problems was Zhilstroysberbank (Otbasy bank). Subsequently, all other commercial banks accepted documents. The regulations on the need to submit relevant documents to receive funds from the fund have been established by the Ministry of Industry and infrastructure development.

\section{Discussions}

The factual bulletin on annuity resources within the world was compiled on the premise of the Benefits Stores in Figures report distributed by the organization for Financial Participation and Improvement (OECD) in June 2020. Kazakhstan was included in the list of expert countries. OECD experts say that the assets of global pension funds in 2019 increased to US \$ 32 trillion, but the impact of the global covid-19 pandemic has reduced these figures. Preliminary figures showed that the assets of pension funds amounted to 32.3 trillion US dollars in OECD countries and 0.7 trillion US dollars in 29 other countries where the analysis was conducted. The maximum amount of pension assets in the US pension funds at the end of 2019 is people (18.8 trillion US dollars), followed by the United Kingdom (3.6 trillion US dollars), Australia (1.8 trillion US dollars), the Netherlands ( 1.7 trillion US 
dollars), Canada (1.5 trillion US dollars), Japan (1.4 trillion US dollars) and Switzerland (1.0 trillion US dollars). Pension assets of these seven countries account for more than $90 \%$ of the total assets of pension funds in OECD countries.

Table 4 - Purpose and directions of use of UAPF savings

\begin{tabular}{|c|c|}
\hline Main purpose & Directions \\
\hline $\begin{array}{l}\text { 1. Repayment of debt in } \\
\text { SLBs }\end{array}$ & $\begin{array}{l}\text { - partial repayment of mortgage housing loan debt (including within the framework } \\
\text { of Islamic bank financing); } \\
\text { - full repayment of mortgage housing loan debt (including within the framework of } \\
\text { financing from the Islamic Bank). }\end{array}$ \\
\hline $\begin{array}{l}\text { 2. repayment of debt in } \\
\text { the Otbasy Bank }\end{array}$ & $\begin{array}{l}\text { - partial repayment of mortgage loan debt under the housing construction savings } \\
\text { system; } \\
\text { - full repayment of mortgage loan debt under the housing construction savings } \\
\text { system; } \\
\text { - refinancing of residential mortgage loans under the system of housing } \\
\text { construction savings. }\end{array}$ \\
\hline $\begin{array}{l}\text { 3. Repayment of arrears } \\
\text { under the right of } \\
\text { redemption agreement }\end{array}$ & $\begin{array}{l}\text { - partial repayment of arrears under the lease agreement with the right of } \\
\text { redemption; } \\
\text { - full repayment of arrears under the lease agreement with the right of redemption. }\end{array}$ \\
\hline 4. Purchase of Housing & $\begin{array}{l}\text { - purchase of housing in private ownership under civil transactions(full } \\
\text { settlement); } \\
\text { - obtaining a mortgage housing loan under the housing construction savings system } \\
\text { in the family bank; } \\
\text { - making a down payment for obtaining a mortgage housing loan for the purchase } \\
\text { of housing (including within the framework of financing from the Islamic Bank). }\end{array}$ \\
\hline 5. Construction & $\begin{array}{l}\text { - individual housing construction (including the purchase of a land plot); } \\
\text { - individual housing construction under the system of housing construction savings } \\
\text { (including the purchase of a land plot). }\end{array}$ \\
\hline 6. Health & $\begin{array}{l}\text { - treatment of orphan diseases; } \\
\text { - reconstructive and reconstructive (plastic) operations; } \\
\text { - radionuclide and radiodtherapy; } \\
\text { - radiosurgical treatment; } \\
\text { - proton therapy; } \\
\text { - ophthalmological services. }\end{array}$ \\
\hline
\end{tabular}

The amount of pension assets increased by $13.9 \%$ in OECD countries and $11.3 \%$ in other countries compared to 2018. The largest increase was in Armenia (58.2\%) and Turkey (37.3\%), where the mandatory individual pension program (2014 in Armenia) or the automatic inclusion program (2017 in Turkey) was recently introduced. At the stage of accumulation of these programs, no one has yet received payment, or few people have received it, as participants are attracted. Pension fund assets exceeded GDP in five countries: Australia (132\%), Iceland (167.6\%), the Netherlands $(191.4 \%)$, Switzerland (141.1\%) and the United Kingdom (123.3\%). In comparison, the assets of pension funds were $20 \%$ lower than GDP in 44 of the 66 countries where the analysis was conducted.

The high return on investment was due to a significant increase in assets in 2019. In 2019, the investment indicators of pension funds were high. The real return of pension funds in 2019 exceeded $5 \%$ in 29 out of 46 countries, and more than $10 \%$ in 13 countries, including the United States (10.1\%). Lithuanian pension funds have achieved the highest real return on investment in 2019 (16.6\%). In general, pension funds showed good investment results in almost all countries where the analysis was conducted in 2019.

OECD experts say that high investment indicators in 2019 may be the result of the recuperation of monetary markets, which lost their memory of significant misfortunes within the final quarter of 2018. At the conclusion of 2019, the most stock showcase files appeared a much higher level than at 
the conclusion of 2018 (for case, agreeing to the Divider Road Diary showcase information center, additionally $25 \%$ for the FTSE 250 , additionally $26.5 \%$ for the DAX and additionally $28.9 \%$ for the S\&P 500) did not achieve a positive investment result: the Czech Republic $(-1.4 \%)$ and Poland $(-2.7 \%)$. Pension funds of the Czech Republic adhere to a conservative investment strategy, which ensured a nominal return on investment $(1.7 \%)$ below the inflation rate $(3.2 \%)$. The low return on Polish domestic securities in 2019 partially affected the inefficient investment indicators of Polish pension funds.

Pension assets are mainly invested in stocks and bonds as of the end of 2019. In 16 of the 36 OECD countries that provided the data, and in 17 of the 28 other countries where the analysis was conducted, more than $75 \%$ of pension asset portfolios consist of stocks and bonds. At the end of 2019 , more than $50 \%$ of pension fund investments were accounted for in two OECD countries (Lithuania and Poland) and in three non-OECD countries (Hong Kong (China), Malawi and Namibia). In 18 OECD countries and 16 out of 29 non-OECD countries, more than half of pension fund investments were made up of bonds. In 2019, the countries where pension assets were most invested in bonds were Albania (94.8\%), Costa Rica (84.5\%), Kazakhstan (85.5\%), Mexico (81.1\%) and Serbia (80.9\%). In a number of countries, pension funds held most of their assets in the form of cash and deposits, for example, in the Czech Republic (23\%) and Korea (39\%) [7-11].

\section{Conclusion}

The spread of the COVID-19 pandemic in the world and its impact on financial markets will reduce indicators for pension assets, according to OECD experts. According to preliminary estimates, as of the end of the 1st quarter of 2020, the assets of pension funds will decrease to 29.8 trillion US dollars, which is $8 \%$ less than at the end of 2019. The decline in pension fund assets is due to the decline in stock markets in the first quarter of 2020. Profitability, as well as dividend and value growth in 2020. in the first quarter, MSCI World (Morgan Stanley Capital International World Index) was ineffective $(-20 \%)$, as well as between $-11 \%$ and $-24 \%$ in the MSCI index for Australia, Canada, Japan, the Netherlands, Switzerland, the United Kingdom and the United States.

The main purpose of the funds collected in the pension fund is to provide citizens with financial support when they reach retirement age. The main task is to determine the state of the Unified accumulative pension fund, to guarantee an improvement in the quality of life of future pensioners by evaluating the effectiveness of their activities. Today, the Republic of Kazakhstan, having entered the path of civilized development, is implementing the most important reforms in all spheres of society. The most complex of these reforms and the most serious direction is reforms in the social sphere. Because, firstly, the socio-economic issue is constantly on the agenda, as it directly affects the life and everyday life of people; secondly, the pension system of the state is always in the center of attention of the population and is subject to its criticism and criticism. Therefore, the pension system is considered as an critical calculate in guaranteeing the population.

\section{REFERENCES}

1 Constitution of the Republic of Kazakhstan.

2 Address of the president of the Republic of Kazakhstan to the people of Kazakhstan "Strategy Kazakhstan-2050 new political course of the established state" dated December 14, 2012.

3 Law of the Republic of Kazakhstan dated June 21, 2013, no. 105-V on pension provision in the Republic of Kazakhstan.

4 Adambekova A.A. The financial market of Kazakhstan: interaction and prospects for the development of its segments / Monograph / Almaty: Ekonomika, 2012. 286 p.

5 Kulpybaev S., Yntykbaeva S.Zh., Melnikov V.D. Finance: Textbook / Almaty: Economics, 2011. 540 p.

6 Iskakov U.M. Financial markets and intermediaries: textbook / Almaty: Economics, 2012. 344 p. 
7 Amanzholov S.A. On the issue of the methodology of rating assessment of accumulative pension funds // Economic Review, 2012, no. 1, pp. 52-62.

8 Tashenov B. Appointment of solidarity pensions: an alternative approach. Al Pari, 2012, no.1. 29 p.

9 Pension system. Information review of the RFCA of the Republic of Kazakhstan, Almaty, 2012. $160 \mathrm{p}$.

10 State of the pension system in Kazakhstan / National Bank of the Republic of Kazakhstan. Economic Review, 2012, no. 2.

11 UAPF official website https://www.enpf.kz/kz/pension-system/world/pensionnye-fondy-v-tsifrakh. php

Б.А. ЖАКУПОВА, *1

э.Ғ.К., доцент.

*e-mail: bakitgul_75kz@mail.ru

С.И. ИГИЛЬМАНОВА, ${ }^{1}$

аға оқытушы.

e-mail: saule72kz@mail.ru

Н.В. КӒЛЮЖНАЯ, ${ }^{1}$

аға оқытушы.

e-mail: nat k-78@mail.ru

Б.С. БЙМБЕТОВА, ${ }^{1}$

аға оқытушы.

e-mail: bikon_s@mail.ru

${ }^{1}$ Қ. Жұбанов атындағы Ақтөбе өңірлік университеті, Қазақстан, Ақтөбе қ.

\title{
ҚАЗАҚСТАН РЕСПУБЛИКАСЫНЫН БІРЫНҒАЙ ЖИНАҚТАУШЫ ЗЕЙНЕТАҚЫ ҚОРЫНЫҢ ҚАРАЖАТЫН ПАЙДАЛАНУ МЕН БАСҚАРУДЫН НЕГІЗГІ БАСЫМДЫҚТАРЫ
}

\begin{abstract}
Андатпа
Мақаланың мақсаты - Қазақстан Республикасының жинақтаушы зейнетақы жүйесінде туындайтын аса маңызды мәселелер бойынша қазіргі нарықтық экономикаға сәйкес азаматтарды зейнетақымен қамсыздандырудың оңтайлы моделін қалыптастыру, оның теориялық, әдістемелік және құқықтық негіздерін нығайту. Қазақстан Республикасы 24 жыл бұрын зейнетақы реформасын бастаған ТМД елдерінің алғашқыларының бірі. Негізгі мақсаты - әрбір қазақстандықтың зейнеткерлік жасқа жеткен кезде өзінің материалдық жағдайы үшін жеке жауапкершілігін белгілеу. Осыған байланысты реформаны іске асыру кезінде мемлекет саясаты ұрпақтар ынтымақтастығы қағидатын қолданудан зейнетақы қорларындағы дербес жинақтарға біртіндеп көшуді көздеді. Қазақстанда зейнетақымен қамсыздандыру реформасы оңтайлы жүргізілді және Дүниежүзілік Банк оны ең табысты реформалардың бірі деп таныды. Жинақтаушы зейнетақы жүйесі ел өмірінде, қор нарығын дамытуда және ұлттық экономиканы жетілдіруде, елдің бәсекеге қабілеттілігін арттыру үшін ішкі жинақтар есебінен ұзақ мерзімді инвестицияларды бөлуде маңызды рөл атқарады. Әлемнің тиімді дамыған 30 елінің қатарына кіру үшін мемлекет халықты зейнетақымен қамсыздандыру деңгейі мен сапасын жақсарту нәтижесінде Қазақстан азаматтары үшін өмір сүрудің жоғары стандарттарын жасады. Бұл үшін халықтың экономикалық және әлеуметтік жағдайларының аса маңызды құрамдас бөліктерінің бірі - Қазақстанда жинақтаушы зейнетақы қорлары одан әрі де дамуы керек, ал зейнетақы жүйесі бәсекеге қабілетті болуы тиіс. Еліміздегі жинақтаушы зейнетақы жүйесінің негізгі тірегі - жинақтаушы зейнетақы қорын жетілдіру және болашақ халықтың негізін қалыптастыратын тиімді зейнетақымен қамсыздандыру болып табылады. Қазіргі жаһандану және қаржы нарықтарының қарқынды дамуы жағдайында бірінші орында - қаржы нарығына қатысушы жинақтаушы зейнетақы қорының қаржылық жағдайы және оның тиімді жұмыс істеуі тұр.
\end{abstract}

Тірек сөздер: зейнетақы, зейнетақы қоры, зейнетақы жүйесі, жинақтар, салымдар, қаражаттар, капитал. 
Б.А. ЖАКУПОВА, ${ }^{\text {* }}$

к.э.н., доцент.

*e-mail: bakitgul75kz@mail.ru

С.И. ИГИЛЬМАНОВА, ${ }^{1}$

ст. преподаватель.

e-mail: saule72kz@mail.ru

Н.В. КӒЛЮЖНАЯ, ${ }^{1}$

ст. преподаватель.

e-mail: natk-78@mail.ru

Б.С. БИМБЕТОВА, ${ }^{1}$

ст. преподаватель.

e-mail: bikon_s@mail.ru

${ }^{1}$ Актюбинский региональный университет им. К. Жубанова, Казахстан, г. Актобе

\title{
ОСНОВНЫЕ ПРИОРИТЕТЫ ИСПОЛЬЗОВАНИЯ \\ И УПРАВЛЕНИЯ СРЕДСТВАМИ ЕДИНОГО НАКОПИТЕЛЬНОГО ПЕНСИОННОГО ФОНДА РЕСПУБЛИКИ КАЗАХСТАН
}

\begin{abstract}
Аннотация
Цель статьи - формирование оптимальной модели пенсионного обеспечения граждан в соответствии с современной рыночной экономикой по важнейшим вопросам, возникающим в накопительной пенсионной системе Республики Казахстан, укрепление ее теоретических, методических и юридических основ. Республика Казахстан является одной из первых стран СНГ, которая начала пенсионную реформу 24 года назад. Основная цель - установление личной ответственности каждого казахстанца за свое материальное положение при достижении пенсионного возраста. В этой связи при реализации реформы политика государства предусматривала постепенный переход от применения принципа сотрудничества поколений к самостоятельным накоплениям в пенсионных фондах. Реформа пенсионного обеспечения в Казахстане была проведена оптимально, и Всемирный банк признал ее одной из самых успешных реформ. Накопительная пенсионная система играет значительную роль в жизни страны, развитии фондового рынка и совершенствовании национальной экономики, распределении долгосрочных инвестиций за счет внутренних накоплений для повышения конкурентоспособности страны. Для вхождения в число 30 эффективно развитых стран мира государством в результате улучшения уровня и качества пенсионного обеспечения населения созданы высокие стандарты жизни для граждан Казахстана. Для этого одной из важнейших составляющих экономических и социальных условий населения является то, что накопительные пенсионные фонды в Казахстане должны развиваться и дальше, а пенсионная система должна быть конкурентоспособной. Основной опорой накопительной пенсионной системы в стране является совершенствование накопительного пенсионного фонда и эффективное пенсионное обеспечение, формирующее основу будущего населения. В условиях современной глобализации и быстрого развития финансовых рынков на первом месте стоит финансовое положение накопительного пенсионного фонда - участника финансового рынка и его эффективное функционирование.
\end{abstract}

Ключевые слова: пенсия, пенсионный фонд, пенсионная система, сбережения, вклады, средства, капитал. 